\title{
The Influence of Role Ambiguity, Emotional Labor and Positive Psychological Capital on Job Stress of Nursing Assistants
}

\author{
Ji-Hye Jang ${ }^{1}$ and Young-soon Choi $^{2}$ \\ ${ }^{1}$ Dept. of Nursing, Gangneung YeongDong University, Korea \\ ${ }^{2}$ Dept. of Nursing, Kangwon National University, Korea. \\ 1'gogh0049@gmail.com,2ysc615@kangwon.ac.kr
}

\begin{abstract}
This study is a descriptive correlation study to identify the role ambiguity, emotional labor, positive psychological capital, and job stress, and to identify the factors affecting the correlation and job stress of each variable. As a result, job stress had a positive correlation with the number of employees and emotional labor and negative correlation with positive psychological capital. Role ambiguity was negatively correlated with work experience and duration of employment, and there was a positively correlation with emotional labor. Positive psychological capital was positively correlated with work experience, role ambiguity, and negative correlation with emotional labor. Based on the above results, we examined role ambiguity, emotional labor, and positive psychological capital that affect job stress of nursing assistants. The results of this study suggest that it is necessary to establish a systematic education and management plan for job stress, which can improve positive psychological capital, reduce role ambiguity and emotional labor.
\end{abstract}

Keywords: Role ambiguity, Emotional labor, Positive psychological capital, Job stress, Nursing assistants

\section{Introduction}

As a lot of hospitals have introduced business management strategies to survive in limitless competition and fast-changing environments, they get to pay attention to customers (patients), who have relatively been neglected meanwhile, and they try to boost their competitiveness and profit by employing strategies to satisfy and impress customers in respond to the needs of patients who are "customers." Specifically, they attempt to achieve commercialization of human feeling to make it happen [1]. Under the circumstances of the limitless competition, the importance of the first-line nursing staff who keep in touch with patients is increasingly stressed.

After nursing assistant was established as one of new occupations, there were 590,975 certified nursing assistants as of the end of 2013 [2], and people who number 30 thousand or more acquire the certification every year. Under the medical laws, nursing assistants are in charge of assisting nursing and treatment. At present, they are responsible for duties related to assisting nursing and treatment for patients in medical institutions.

Role ambiguity is defined as a process that individuals undergo when they aren't accurately aware of their work and when they feel there isn't sufficient information necessary for the job

Article history:

Received (January 17, 2018), Review Result (February 26, 2018), Accepted (March 31, 2018) 
performance [3]. Also, that is defined as a degree of psychological burden that is caused by unclarified organizational objectives, unclear evaluation standards for job performance, a lack of information required for job performance or poor awareness [4]. Arthur [5] argued that role ambiguity affects the performance of organizational members in a negative way. Many studies have examined role ambiguity in various fields such as that of employees, secretaries, airline workers or teachers [6][7], but not many studies have yet investigated the role ambiguity of nursing assistants.

Emotional labor refers to the endeavor, plan and control that are necessary for organizational members to express the kind of emotion that the organizations to which they belong demand while keeping in touch with others, and that also means to regulate one's own emotion to give satisfaction to customers while providing them with services [8].

Positive psychological capital refers to a degree of positive cognitive state toward achievement and success. That consists of four concepts: self-efficacy, hope, optimism and resilience [9].

Stress is an emotional state that is detrimental to an organism. In a recent concept, that could be said as a universal response to a specific requirement [10]. Job stress is defined as what makes it difficult for individuals to perform their job due to something related to that or as interactions between the job performer and job-related factors that lead to the change of psychological or physical conditions [11].

In terms of health care services, the stress of hospital employees affects the service providers themselves in various ways, and that ultimately exerts an influence on the quality of the health care services that they offer. That is, chronic stress might result in detracting from health care professionals' ability to provide quality health care services, and from their attention and problem-solving skills as well [12].

Nursing assistants should properly respond to various situations or difficulties that take place during job performance, and the positive role of positive psychological capital is of great importance for that. Positive psychological capital is said to contribute to lowering job stress because that makes it possible to overcome diverse possible hardships and perform one's job with confidence [13].

As for domestic earlier studies on role ambiguity, emotional labor, positive psychological capital and job stress up to date, lots of studies have mainly examined workers in the service industry, hotel employees and call center workers. In the case of studies on medical institutions and health care workers, most studies have investigated university hospitals and nurses, and not many studies have yet attempted to investigate nursing assistants.

The purpose of this study was to examine the levels of role ambiguity, emotional labor, positive psychological capital and job stress among nursing assistants, the correlations of the variables and influential factors for job stress in an attempt to provide some information on how to improve their work.

\section{Research method}

\subsection{Research design}

This study is a descriptive correlation study to identify the role ambiguity, emotional labor, positive psychological capital, and job stress, and to identify the factors affecting the correlation and job stress of each variable.

\subsection{Research subjects}


The subjects of this study were the nursing assistants who visited the training center of 'Nursing Assistants Association', the number of subjects was selected by referring to previous studies. The sample size was calculated using the $G *$ power 3.1 program. Based on the regression analysis, the effect size was 0.08 , significance level was .05 , power was .95 , and a minimum of 315 subjects were needed. Considering the dropout rate $(15 \%)$, the number of subjects was 360 and the final 332 subjects were excluded, except for 28 subjects whose answers were insufficient.

\subsection{Research tools}

\subsubsection{Role ambiguity}

Role ambiguity occurs when information about one's job and responsibility is uncertain. In this study, we used a tool developed by Schuler, Aldag and Brief [14]. The Cronbach's $\alpha$ value of this study was .881.

\subsubsection{Emotional labor}

Emotional labor was first presented by Hochschild [15], as part of the job role, emotional management to create expressions and behaviors that should be publicly observed. In this study, we used to revise the tools separated by a surface behavior and inner behavior of Hochschild. The Cronbach's $\alpha$ value of this study was .686.

\subsubsection{Positive psychological capital}

Positive psychological capital is the degree of positive perception of an individual towards achievement and success [9], in this study, a tool developed by Lauver and Kristof-Brown was used. The Cronbach's $\alpha$ value of this study was .906 .

\subsubsection{Job stress}

Job stress was assessed by Chang, Se-jin [16] and modified for the Korean job stress basic type measurement tool. The Likert scale consists of 6 items. Cronbach's $\alpha$ value was .802 in this study.

\subsection{Data collection methods}

The data collection period of this study was from April 1, 2017 to June 30, 2017. Before the data collection, the purpose of the study, data collection and disposal method of data were explained. After that, the subjects who agreed to the data collection received the written consent and then conducted the questionnaire. In the case of withdrawing the questionnaire during the questionnaire, it was shown that there was no disadvantage, and the average time for questionnaire was about 15 minutes.

\subsection{Data analysis methods}

The collected data were analyzed using the SPSS 21.0 program, and the details are as follows. Stepwise multiple regression was performed to identify factors affecting the subject's job stress. The collected data were analyzed using the SPSS 19.0 program according to the purpose of the study. To determine the demographic characteristics and health-related characteristics of the subjects, the actual number, percentages, mean and standard deviation 
were obtained. Chi-Square test, Fisher's Exact test and independent t-test were used for the homogeneity test between experimental group and control group. The normality test of the research variables was confirmed by Kolmogorov-Smirnovtest. In order to minimize the error between the groups that may exist before the experiment, the values of the normal distribution are analyzed by the independent t-test.

\section{Results and Discussion}

\subsection{Correlation between positive psychological capital and job stress of subjects}

Stepwise regression analysis was conducted to determine the effect of factors on job stress of the subjects. Univariate analysis showed that emotional labor and positive psychological capital, including age, region, and number of employees, which were statistically significant, were selected as the final variables, and the regions were treated as dummy variables. The tolerance limit between independent variables was $0.961-0.986$, which was more than 0.1 , the Variance Inflation Factors (VIF) were 1.014 - 1.040, which is below the reference value of 10 , thus eliminating the multi-collinearity problem. In addition, Durbin-Watson value was verified to verify the independence of the residuals. As a result, it was 2.016, which was close to the reference value 2 , so that there was no autocorrelation. The results of the multiple regression analysis showed that factors affecting the job stress of the subjects were age, Seoul area, Incheon area, emotional labor, number of employees, and the explanatory power of the model was $9.8 \%(\mathrm{~F}=8.12, \mathrm{p}<.001)$ [Table 1$]$.

Table 1. Correlation between the job stress, role ambiguity, emotional labor, positive psychological capita of subjects

\begin{tabular}{|c|c|c|c|c|c|c|c|}
\hline & $\begin{array}{c}\text { Work } \\
\text { Experience } \\
\mathrm{R}(p)\end{array}$ & $\begin{array}{c}\text { Employment } \\
\text { Period } \\
\mathrm{R}(p)\end{array}$ & $\begin{array}{c}\text { Number } \\
\text { Of } \\
\text { employees } \\
\mathrm{R}(p)\end{array}$ & $\begin{array}{c}\text { Role } \\
\text { Ambiguity } \\
\mathrm{R}(p)\end{array}$ & $\begin{array}{l}\text { Emotional } \\
\text { Labor } \\
\mathrm{R}(p)\end{array}$ & $\begin{array}{c}\text { Positive } \\
\text { Psychological } \\
\text { Capital } \\
\mathrm{R}(p)\end{array}$ & $\begin{array}{c}\text { Job stress } \\
\mathrm{R}(p)\end{array}$ \\
\hline $\begin{array}{c}\text { Work } \\
\text { experience }\end{array}$ & 1 & - & - & - & - & - & - \\
\hline $\begin{array}{c}\text { Employment } \\
\text { Period }\end{array}$ & $\begin{array}{c}.591^{* *} \\
(<.001)\end{array}$ & 1 & - & - & - & - & - \\
\hline $\begin{array}{l}\text { Number of } \\
\text { Employees }\end{array}$ & $\begin{array}{l}.077 \\
(.166)\end{array}$ & $\begin{array}{l}.054 \\
(.326)\end{array}$ & 1 & - & - & - & - \\
\hline $\begin{array}{c}\text { Role } \\
\text { Ambiguity }\end{array}$ & $\begin{array}{l}-.274^{* *} \\
(<.001)\end{array}$ & $\begin{array}{l}-.169^{* *} \\
(.002)\end{array}$ & $\begin{array}{l}-.093 \\
(.092)\end{array}$ & 1 & - & - & - \\
\hline $\begin{array}{l}\text { Emotional } \\
\text { Labor }\end{array}$ & $\begin{array}{l}-.057 \\
(.304)\end{array}$ & $\begin{array}{l}-.034 \\
(.540)\end{array}$ & $\begin{array}{l}.050 \\
(.364)\end{array}$ & $\begin{array}{l}.456^{* *} \\
(<.001)\end{array}$ & 1 & - & - \\
\hline $\begin{array}{c}\text { Positive } \\
\text { Psychological } \\
\text { Capital }\end{array}$ & $\begin{array}{l}.198^{* * *} \\
(<.001)\end{array}$ & $\begin{array}{c}.062 \\
(.262)\end{array}$ & $\begin{array}{l}-.013 \\
(.815)\end{array}$ & $\begin{array}{l}-.618^{* *} \\
(<.001)\end{array}$ & $\begin{array}{l}-.454^{* *} \\
(<.001)\end{array}$ & 1 & - \\
\hline Job stress & $\begin{array}{l}-.065 \\
(.242)\end{array}$ & $\begin{array}{l}-.078 \\
(.157)\end{array}$ & $\begin{array}{l}.142^{* *} \\
(.010)\end{array}$ & $\begin{array}{l}.048 \\
(.387)\end{array}$ & $\begin{array}{l}.160^{* *} \\
(.004)\end{array}$ & $\begin{array}{l}-.170^{* *} \\
(.002)\end{array}$ & 1 \\
\hline
\end{tabular}




\subsection{Factors affecting subject's job stress}

Job stress of the subjects showed a statistically significant positive correlation between number of employees in the $(\mathrm{r}=.142, \mathrm{p}=.010)$, emotional labor $(\mathrm{r}=.160, \mathrm{p}=.004)$, positive psychological capital $(\mathrm{r}=-.170, \mathrm{p}=.002)$ was inversely correlated [Table 2]. Role ambiguity had a statistically significant negative correlation with work experience $(r=-.274, \mathrm{p}<.001)$ and duration of employment $(\mathrm{r}=-.169, \mathrm{p}=.002)$, there was a statistically significant positive correlation with emotional labor $(\mathrm{r}=.456, \mathrm{p}<.001)$. Positive psychological capital had a positive correlation with work experience $(\mathrm{r}=.198, \mathrm{p}<.001)$, there was a statistically significant negative correlation with role ambiguity $(\mathrm{r}=-.618, \mathrm{p}<.001)$ and emotional labor $(\mathrm{r}=-.454, \mathrm{p}<.001)$.

Table 2. Job stress of influencing factor

\begin{tabular}{|c|c|c|c|c|c|}
\hline & $\mathrm{B}$ & $\mathrm{SE}$ & $\beta$ & $\mathrm{t}$ & $\mathrm{p}$ \\
\hline (Constant) & 14.500 & 1.973 & & 7.350 & $<.001$ \\
\hline Age & -0.852 & 0.230 & -.197 & -3.709 & $<.001$ \\
\hline District_Seoul & -2.063 & 0.787 & -.140 & -2.622 & .009 \\
\hline District_Inchon & 1.661 & 0.051 & .145 & 2.754 & .006 \\
\hline Emotional labor & 0.139 & 0.740 & .119 & 2.245 & .025 \\
\hline Number of employees & 0.006 & 0.003 & .108 & 2.053 & .041 \\
\hline Adj. $R 2=.098, F=8.12, p<.001$ & & & & \\
\hline
\end{tabular}

\section{Conclusions}

This study is a descriptive correlation study to identify the role ambiguity, emotional labor, positive psychological capital, and job stress, and to identify the factors affecting the correlation and job stress of each variable.

As a result, the relationship between job ambiguity, positive psychological capital, emotional labor and job stress showed that job stress had a positive correlation with the number of employees and emotional labor and negative correlation with positive psychological capital. Role ambiguity was negatively correlated with work experience and duration of employment, and there was a positively correlation with emotional labor. Positive psychological capital was positively correlated with work experience, role ambiguity, and negative correlation with emotional labor. Based on the above results, we examined role ambiguity, emotional labor, and positive psychological capital that affect job stress of nursing assistants.

\section{References}

[1] H.A. Kang, "Change of nursing profession labor," Economy and Society, vol.55, no.3, 142-168, (2002)

[2] Health Insurance Review and Assessment Service, Statistical Yearbook of Health Insurance, pp.179-182, (2013)

[3] Churchill Jr G.A. Ford, N.M. Hartley, and S.W. Walker, "The determinants of salesperson performance: A meta-analysis,” Journal of Marketing Research, vol.22, no.2, pp.103-118, (1985)

[4] Rizzo J. R., House R. J., and Lirtzman S. I. "Role conflict and ambiguity in complex organizations," Administrative Science Quarterly, vol.15, no.2, pp.150-163, (1970) 
[5] Arthur, J. B., "Effects of human resources systems on manufacturing performance and turnover," Academy of Management Journal, vol.37, no.3, pp.670-687, (1994)

[6] Papastylianou A., Kaila M., and Polychronopoulos M. "Teachers' burnout, depression, role ambiguity and conflict," Social Psychology of Education, vol.12, no.3, pp.295-314, (2009)

[7] H. J. Choi and H. G. Kown, "The stress influences on the job attitudes toward the employees of construction industries," Korea J of Business Administration, vol.21, no.4, pp.1723-1749, (2008)

[8] B. Y. Park, "The relationship of emotional labor with professional quality of life in general hospital personnel," Ph. D. dissertation, Chosun University, (2012).

[9] Luthans F., Youssef C. M., and Avolio B. J. "Psychological capital developing the human competitive edge," Oxford, UK: Oxford University Press, (2007).

[10] Seyle H. A., "The stress of life, in T.A. Beehr and T.M. Franz(Eds.), the current debate about the meaning of job stress," Journal of Organizational Behavior, (1986).

[11] Beehr. T.A. and J.E. Newman. "Job stress and employee health and organizational effectivess: A fact analysis," Model and Literature Review. Personal Psychology, vol.31, pp.665-669, (1978)

[12] W. C. Lee and W. G. Yoo, "A study on occupational stress of hospital workers," Journal of Gyeongsan University, (1997).

[13] K.O. Go, S.K. Park, and M.H. Lee, "The effect of positive psychological competence of clinical nurse on burnout," J Korean Acad Nurs Adm., vol.19, no.2, pp.304-314, (2013)

[14] Schuler, R. S., Aldag, R. J., and Brief, A. P. "Role conflict and ambiguity: A scale analysis," Organizational Behavior and Human Performance, vol..20, no.1, pp.111-128, (1977)

[15] Hochschild A.R. "The managed heart: Commercialization of human feeling," University of California Press, Berkeley, CA. (1983).

[16] S.J. Chang, "Current stress and situation of job stresses in Korea," Korean Society for Preventive Medicine, vol.2, no.1, pp.9-36, (2002) 